\title{
Generation of socio-environmental indicators in the territorial structure of San Luis Huexotla, Texcoco, México
}

\author{
Espinosa-Morales, Juan Carlos ${ }^{1 *} ;$ Escalona-Maurice, Miguel J. ${ }^{1}$; Ortega-Méndez, Claudia Ivon ${ }^{1}$; Hernández-Juárez, Martín ${ }^{1}$ \\ ${ }^{1}$ Colegio de Postgraduados, Campus Montecillo, Texcoco, Estado de México. \\ *Corresponding author: espinosa.carlos@acolpos.mx
}

\begin{abstract}
Objective: This article aims to show the statistical density of the population per block, to know its effect as a critical spatial result and its relationship with some socio-environmental indicators, this analysis-process incorporates statistical data and geographic information systems as a model for territorial spatial analysis, which shows the relationship between demand and generation of services.
\end{abstract}

Design/Methodology/Approach: The Urban Basic Geostatistical Units data of INEGI (the Spanish acronym of the National Geostatistical Information Institute in Mexico) was used on block-level as: number of inhabitants and number of dwellings. It was associated with variables identified by exploring those key stakeholders at the locality (Delegates, and the Council for Citizenship Participation (in Spanish, COPACI), as well as the Huexotla Ejido Commissariat, their clergy representative and some other key informants. In addition, GIS were used to digitize vector information and to integrate a relational database for the geospatial analysis of the variables, data and indicators in order to obtain zoning maps.

Results: This study presents a proposal for the generation of socio-environmental indicators that can be used in territorial analysis with urban and rural applications using Geographic Information Systems as a tool.

Study limitations: Transition processes converge in geographic transformation and, consequently have effects on landscape changes; demand for public services; and solid waste generation.

Findings/Conclusions: The size of the scale used for the locality analysis contributes to determine the territorial planning of a geographical space. Thus, results obtained deliver information for planning in the decision-making processes at localities in rural to urban transitional zones.

Keywords: Geographic Information Systems, socio-environmental indicators, territorial structure.

\section{INTRODUCCIÓN}

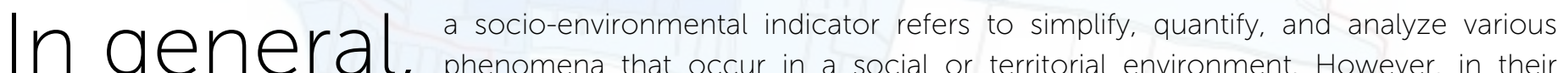
classification, there are specific environmental indicators as well as social or economic indicators, etc., that explicitly measure their own objective. Because of that, depending on their origin, merging two indicators seeks to integrate physical and technological aspects in order to consider sustainability, and the economic and social systems at different scales and levels (Dixon and Fallon, 1991).

Agroproductividad: Vol. 14, Núm. 4, abril. 2021.pp: 105-111.

Recibido: octubre, 2020. Aceptado: marzo, 2021. 
Globally, environmental indicators are used to statistically measure the impacts on phenomena such as climate, soil, and species, air quality, etc. that society has generated on environment in a particular territorial space. Some organizations like OECD (Organization for Economic Co-operation and Development) define a set of indicators as base information for periodic assessments of the environmental care performance in different countries of the organization (OECD, 1993). In Mexico, SEMARNAT, through Dirección General de Estadística e Información Ambiental (one of its Directorate Departments), is responsible for the development and updating of the National Environmental Indicator System (SNIA, the acronym in Spanish). This system has interrelation with the National System of Environmental and Natural Resources (in Spanish, SNIARN), which responsibility is to collect, organize and communicate environmental and natural resources information in Mexico. Both systems integrate statistical, geographical and documentary databases that are updated with the information generated by different entities of the Federal, state and municipality levels of government; in order to provide reliable and opportune information for decisionmaking (SEMARNAT, 2018).

The aim of this article is to explain how to use environmental indicators as an important tool for territorial planning and decision-making processes affecting actions within a geographical area. Such indicators specify how the variable is behaving over the territorial structure; so, they become keys to evaluate and predict trends expressed in reality.

Therefore, indicators are a necessary tool to measure or classify a phenomenon. In this study-case some indicators are considered to acknowledge some important aspects in a territorial space. This study-case includes indicators, based on the areas from a locality, that monitor the problems classified as important by the surveyed stakeholders.

Population dynamics is a function of a territorial pattern, which explains population growth by various factors depending one on each other; as it is the case of variables such as birth, mortality, migration, and immigration. These can have transitions that affect mobility such as environmental or spatial factors that characterize a certain location (Molero, 2007). However, it is essential to observe historical growth rates to get a projection based on growth indexes and to perform demographic calculations on the series of population censuses that occur in Mexico every 10 years. The relationship between the number of people per unit of area in a territorial space is called population density (INEGI, 2010).

The state of Mexico has suffered changes in its surface, due to overcrowding and territorial density. According to statistical data, the state of Mexico has an area of 22 , $487.85 \mathrm{~km}^{2}$; the population density was 582 inhabitants per $\mathrm{km}^{2}$ in 2000, but in 2010 population density grew to 675 inhabitants per $\mathrm{km}^{2}$ and in 2015, it was 720 inhabitants per $\mathrm{km}^{2}$. This means an observed increase in the total population figure from 13096686 (2000) to 16187608 inhabitants in 2015 (INEGI, 2015).

Regarding the municipality of Texcoco, it has a surface of $422.53 \mathrm{~km}^{2}$; the population density was 483 inhabitants per $\mathrm{km}^{2}$ in 2000, and it reached 570 inhabitants per km² in 2015. Total population increased from 204102 (2000) to 240749 in 2015 (H. Ayuntamiento of Texcoco, 2016). The studied locality (San Luis Huexotla) has an area of $9.52 \mathrm{~km}^{2}$ and a total of 12269 inhabitants in 2010; this means a population density of 1288 inhabitants per $\mathrm{km}^{2}$ in that year.

\section{MATERIALS AND METHODS a) Statistical information}

Statistical information was collected from the results of the 2010 INEGl census with information at block-level of statistical data such as number of inhabitants and number of dwellings.

The considerations of the official census and yearbook data of the study area for the case of San Luis Huexotla, a locality belonging to the Municipality of Texcoco, were taken independently due to its structural conception by INEGI.

Throughout history, San Luis Huexotla has modified its territory due to various circumstances and because there is no definition of limits by any governmental authority, its delimitation is based on considerations of the local authorities who administer and regulate the actions of the locality; its population is also territorially recognized by their uses and customs.

To carry out this study, it was considered to take as a reference the territorial delimitation made by the INEGI from the year 1990, a geographical modification that was 


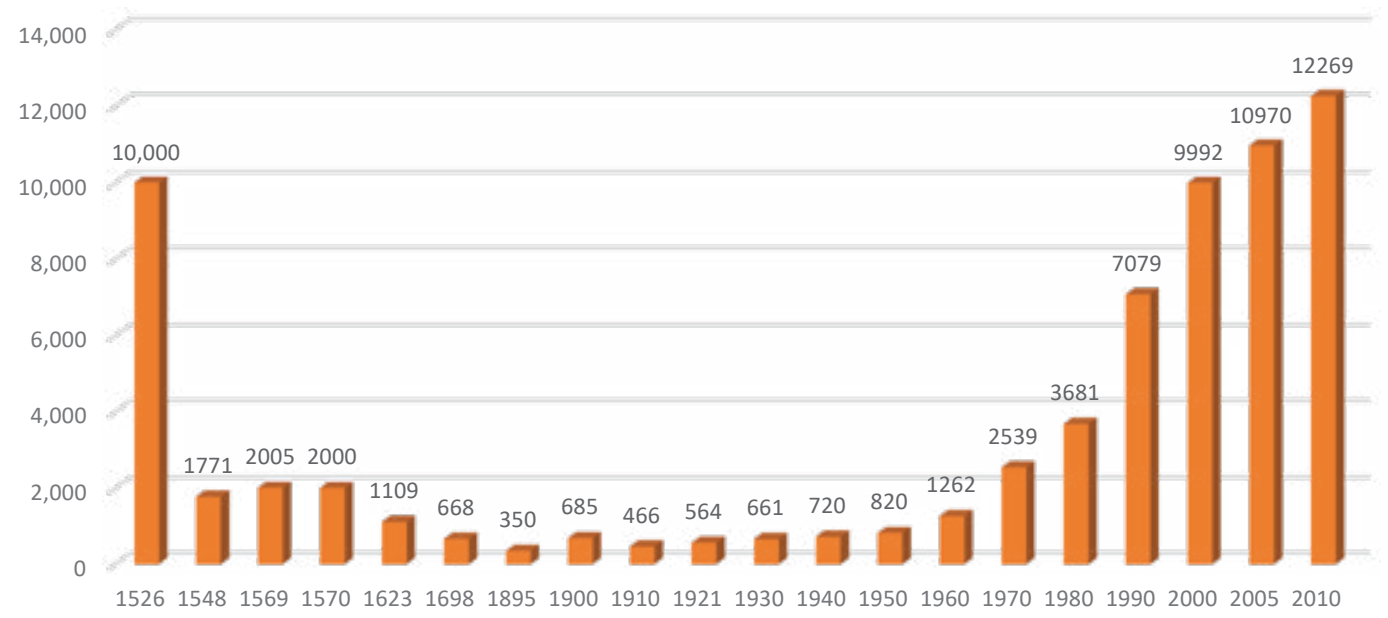

Figure 1. Historical population growth at San Luis Huexotla (Espinosa, 2017).

implemented by that Institute, in order to guarantee the national geographic coverage of the General Census of Population and Housing No. XI. It is stated as well, that in cases such as Huexotla which had some modifications, this data had a code number and statistical information registered. However, such coded data were discarded in 1980, and Huexotla was integrated as a conurbation into the Municipality of Texcoco de Mora, México (Figure 1).

Due to the merging and subsequent integration as a metropolitan area, Huexotla lost its code and name in the National Geostatistical Framework (Marco Geoestadístico Nacional) and became a part of the urban Texcoco,

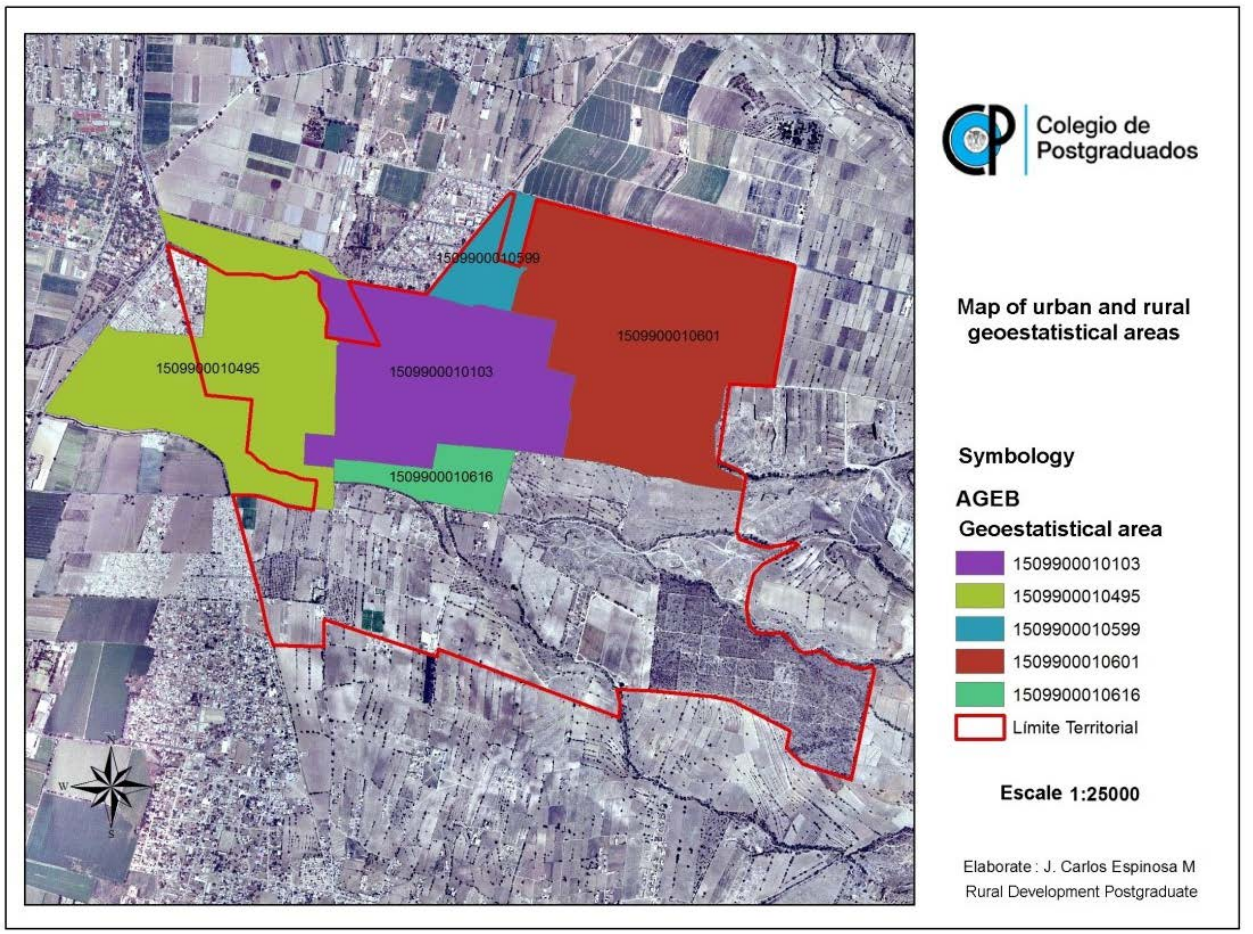

Figure 2. Map of urban and rural geostatistical areas of San Luis Huexotla. thus sharing features of a population greater than 2500 inhabitants. The division of geostatistical areas includes three levels of desegregation: state (AGEE), municipal (AGEM) and basic (AGEB), the latter divided into rural and urban (INEGI, 2010b). Huexotla is territorially integrated by 5 urban AGEBs (basic geostatistical units), and rural/ Ejidal zones, delimited as (Figure 2).

\section{b) Interviews with local key informants}

To obtain additional information in this research, we resorted looking for stakeholders within the locality (a.k.a., key informants), who have privileged information that will allow understanding some important elements of the locality. By applying 50 surveys taking a sample from a total of 181 ejidatarios. The key informants according to Martínez (1991) are those "people with special knowledge, status and good information capacity". In our selection, the informants considered pertinent to address the research topic were some auxiliary authorities (Delegates), the former commissariate of the ejido, historians at the locality, clergy representative, the commissioned anthropologist in the INAH zone. The information obtained with each of the key stakeholders helped to determine four indicators (population density, housing, water consumption, and solid waste production). 


\section{c) Geographic Information Systems}

SPOT 6 satellite image. Two images were obtained from the Federal Government remote station (ERMEX NG1) of satellite images from the SPOT 6 satellite. That image was authorized for this investigation (Internal application Num. 101251/0233-2016), with a resolution of $1.5 \mathrm{~m}$ in the panchromatic image, which was processed for geometric correction (Espinosa, 2017).

For the digitization of the locality, the INEGI orthocorrected 1996 photo from SPOT 6, dated May 4, 2016 and the QGis 10.4 software were used. Using each segment, a table of attributes was filled in to identify polygons by color, identifier and name. When digitizing the segments, care was taken to close the units, especially in urban blocks and those buildings where intersections, closure of polygons or segments overlapping were not obtained (Bosque, 1997 and Ortega, 2016).

In the field verification, the following tools were used:

- Verification points were determined, and they were georeferenced by geographic coordinates.

- Data collection with GPS.

- Drone flight and collection of photographic images.

- Georeferencing of drone images, based on the 2007 Orthophoto.

\section{RESULTS AND DISCUSSION The socioeconomic indicators}

a) Population density. The idea of measuring population density is to estimate the number of people living in a geographic space. According to statistical data, the state of Mexico has an area of $22487.85 \mathrm{~km}^{2}$ and the population density was 582 inhabitants per $\mathrm{km}^{2}$ in 2000; 675 inhabitants per $\mathrm{km}^{2}$ in 2010, and 720 inhabitants per $\mathrm{km}^{2}$ in 2015. An increase in the population was observed, with a total of 13096686 inhabitants in 2000 to 16187608 in 2015 (H. Ayuntamiento de Texcoco, 2016). The municipality of Texcoco has an area of 422.53 $\mathrm{km}^{2}$, and the population density increased from 483 inhabitants per $\mathrm{km}^{2}$ in 2000 to 570 inhabitants per $\mathrm{km}^{2}$ in 2015. Total population escalated from 204102 (in 2000) to 240749 in 2015 (H. Ayuntamiento de Texcoco, 2016). In the following map, based on statistical data at blocklevel from the INEGI 2010 Census of Population and Housing, population density was classified per squareblock (Figure 3).

b) Housing density per square-block. In the state of Mexico, the number of dwellings is 3432 480. Texcoco has 51007 houses and Huexotla accounts for 6.9\% of total housing in Texcoco, this is, 3514 dwellings according to the 2010 INEGI Population and Housing Census. In the following map we can see the population density per block at Huexotla.

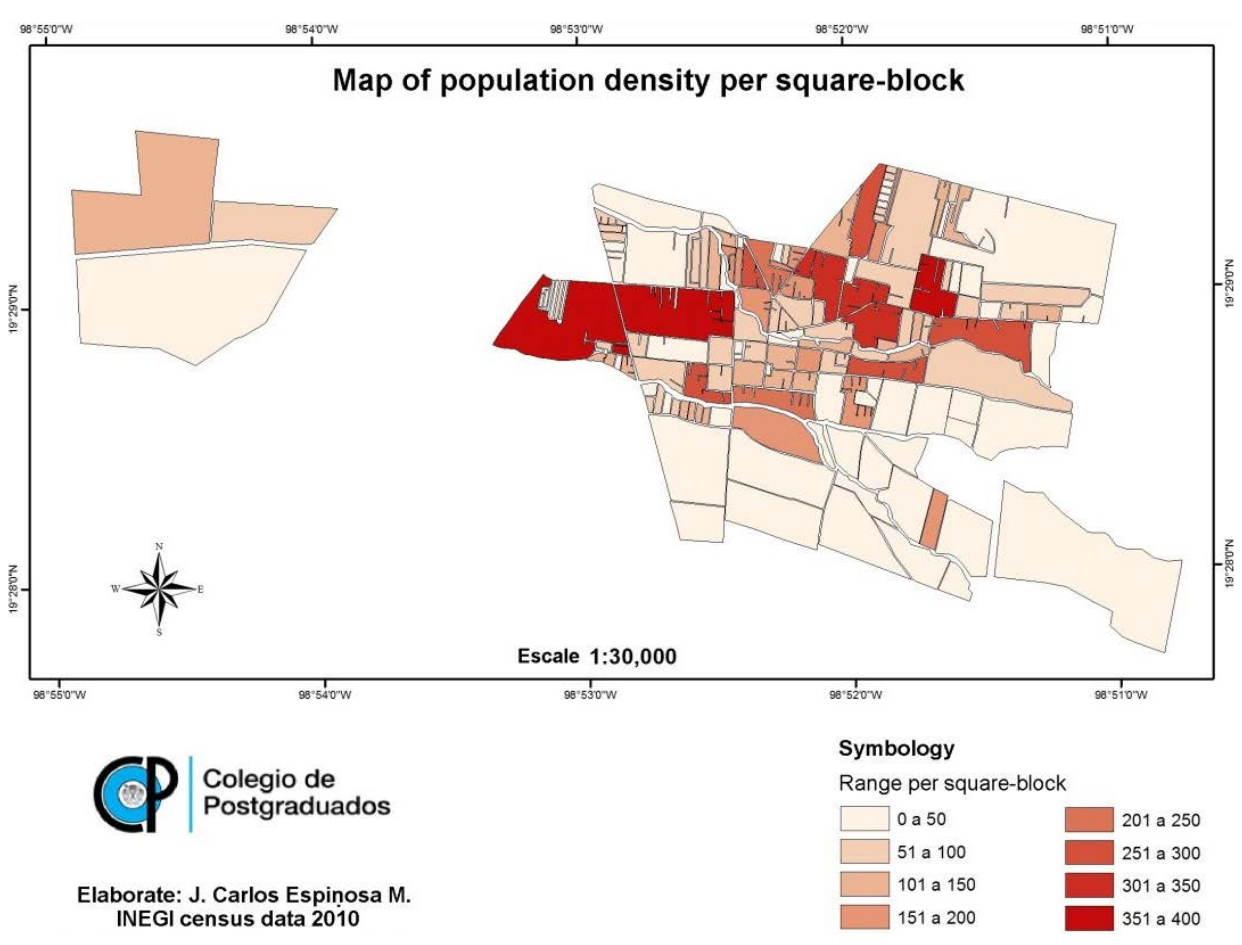

Figure 3. Map of population density per square-block.
The ranges defined in the projection of this map of housing density per block were divided into class intervals from 0-9 up to more-than-110 dwellings. The class that shows the highest density of dwellings is the one located in the western area of the town with 111 dwellings and a population of 338 people in an area of 23 ha (Figure 4).

\section{Environmental indicators}

a) Water consumption and demand

The characteristic land uses, as well as the conservation of natural resources are customary to the population of Huexotla. Natural resources 

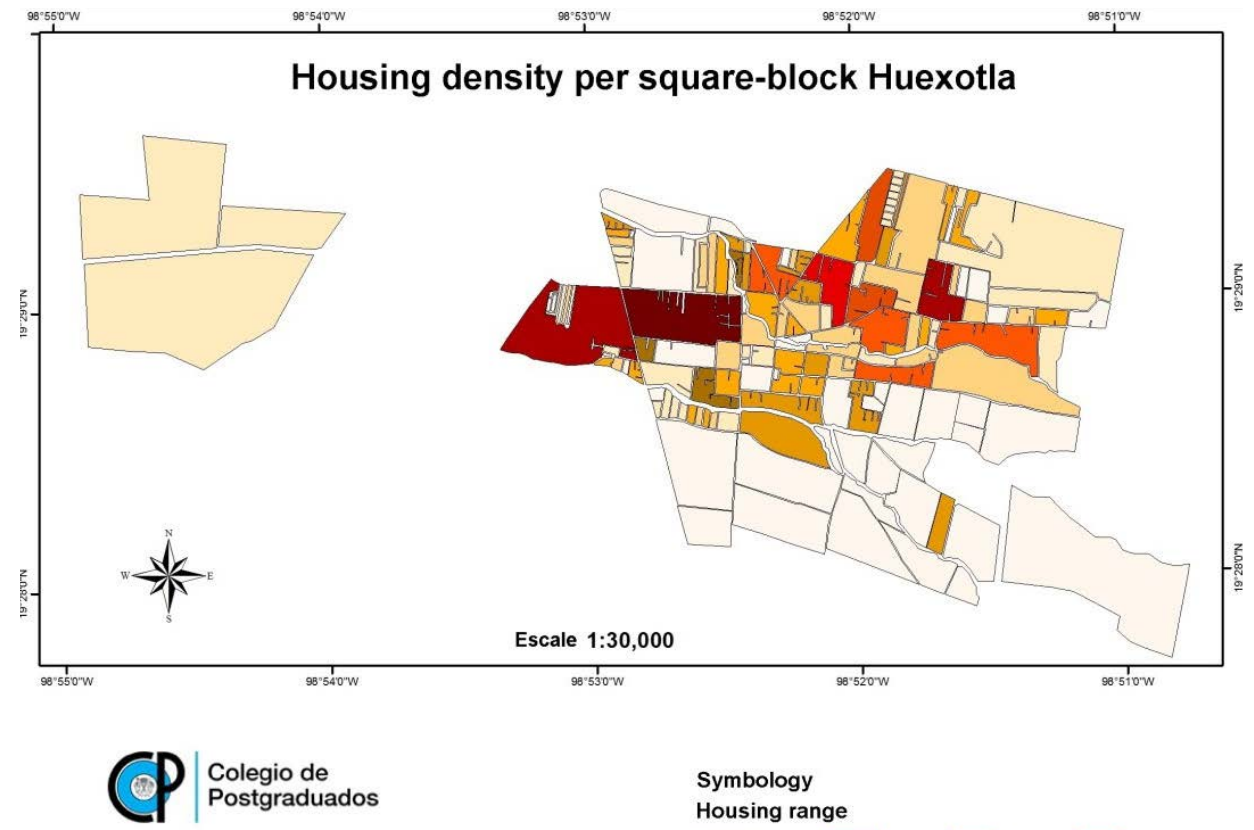

Elaborate: J. Carlos Espinosa M. INEGI census data 2010

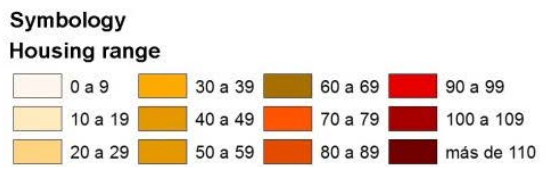

Because water is a primary resource for human beings, its consumption should be moderate since according to CONAGUA (2009) in Mexico around 320 liters are used per inhabitant per day. This estimation is pertaining only to domestic use by individual. In the following figure we observe the annual tap water demand by population size and per block. Annual water consumption is estimated to be $1433019.2 \mathrm{~m}^{3}$ (Figure 5).

In Huexotla there are 3514 dwellings that are inhabited by 3 to 5 people apiece, according to the INEGI estimates in 2010. Of that housing total in the

Figure 4. Map of housing density per square-block.

and their degradation rates can be decisive for their conservation, the levels of pollution of water and soils as well as the generation of solid waste are some of those factors resulting from the increase in urbanization. The Sistema Nacional de Indicadores Ambientales (SNIA) integrates 14 indicators that seek to evaluate the progress in the conservation and sustainable use of the environment and natural resources in the country (SEMARNAT, 2016). Some of them are biodiversity, solid waste, atmosphere, water, soil and forest. The importance of analyzing the condition of some indicators at Huexotla is a proof of the condition of its territorial space, the increase in demand for services and the conservation of them. This knowledge makes feasible to carry out resource analysis and decision making for conservation.

Water supply is used mainly by the population, but it is also a major input for agricultural activities and industry (Kimoon, 2000). Water use should be moderate, since its excessive demand can cause problems as the overexploitation of aquifers, that would risk supply of the resource in the future (SEMARNAT, 2016). Huexotla has wells for the distribution and service of tap water, which are considered in the Table 1.

\begin{tabular}{l|c}
\multicolumn{1}{c|}{ Table 1. Public water wells. } \\
\hline Socation & Number of wells \\
\hline San Mateo Huexotla & 2 \\
\hline San Nicolás Huexotla & 1 \\
\hline Sector Popular & 1 \\
\hline Bellavista & 1 \\
\hline Fraccionamiento Prywer & 1 \\
\hline
\end{tabular}

town, 3258 are in the urban area, and only 2614 get piped water as a public service; the 256 remaining dwellings are in rural areas and these figures are not considered in the AGEBs delimited for the study area. The following map shows the percentage of piped water supply respect to the number of dwellings, the data considered represents the territorial area of urban AGEBs of Texcoco (Figure 6).

\section{b) Solid waste production}

The inadequate management of solid waste can cause a lot of problems, especially on natural resources such as air quality, soil, ground water and surface water. Main effects on humans are diseases, and others indirect as, loss of fauna and landscape deterioration (SEMARTNAT, 2016). Within the waste produced by the inhabitants, several types of solid waste are considered (litter, paper and cardboard, plastics, glass, and metals, among others). Currently the production of solid waste in Mexico is $1.2 \mathrm{~kg}$ per person per day according to The World Bank (2012); this figure means for Huexotla a solid waste gross production of 14.7 tons / day in 2010 (Table 2).

The dwellings with drainage are 2818 out of 3514 (total dwellings). 


\section{CONCLUSIONS}

Huexotla, considered a town with abundant and important agricultural spaces, and identified as a population with farming characteristics, has undergone a process of territorial transformation in terms of structure, modifying its social, economic and cultural activities.

As it was possible to observe in the results obtained from the maps of Population and Housing density, there is an important growth showing that the surface area used for housing is in the central part of the town, but its growing areas are classified as Rural Geostatistical basic units (in Spanish, AGEBs).

The environmental analysis also shows an increase in the demand for public services (water, electricity, drainage), and generation of waste or polluting residues. In 2010 there were 3 514 inhabited dwellings with 3 to 5 people each, which required 1 $433019.2 \mathrm{~m}^{3}$ of water per year and generated 5373.8 tons of solid waste per year.

In the end, this study is considered pertinent to generate strategies for local authorities regarding the distribution of main services such as water; and to consider the amount of solid waste generated per number of inhabitants in the locality.

\section{REFERENCES}

Bosque S. J. (1997). Sistemas de información geográfica, Ed. Rialp. $2 a$ ed. Madrid. 451p

Banco Mundial (2012). What a Waste: A Global Review of Solid Waste Management. http://web.worldbank.org/WBSITE/ EXTERNAL/TOPICS/EXTURBANDEVELOPMENT/0, conte ntMDK:23172887 pagePK:210058 piPK:210062 theSite PK:337178,00.html

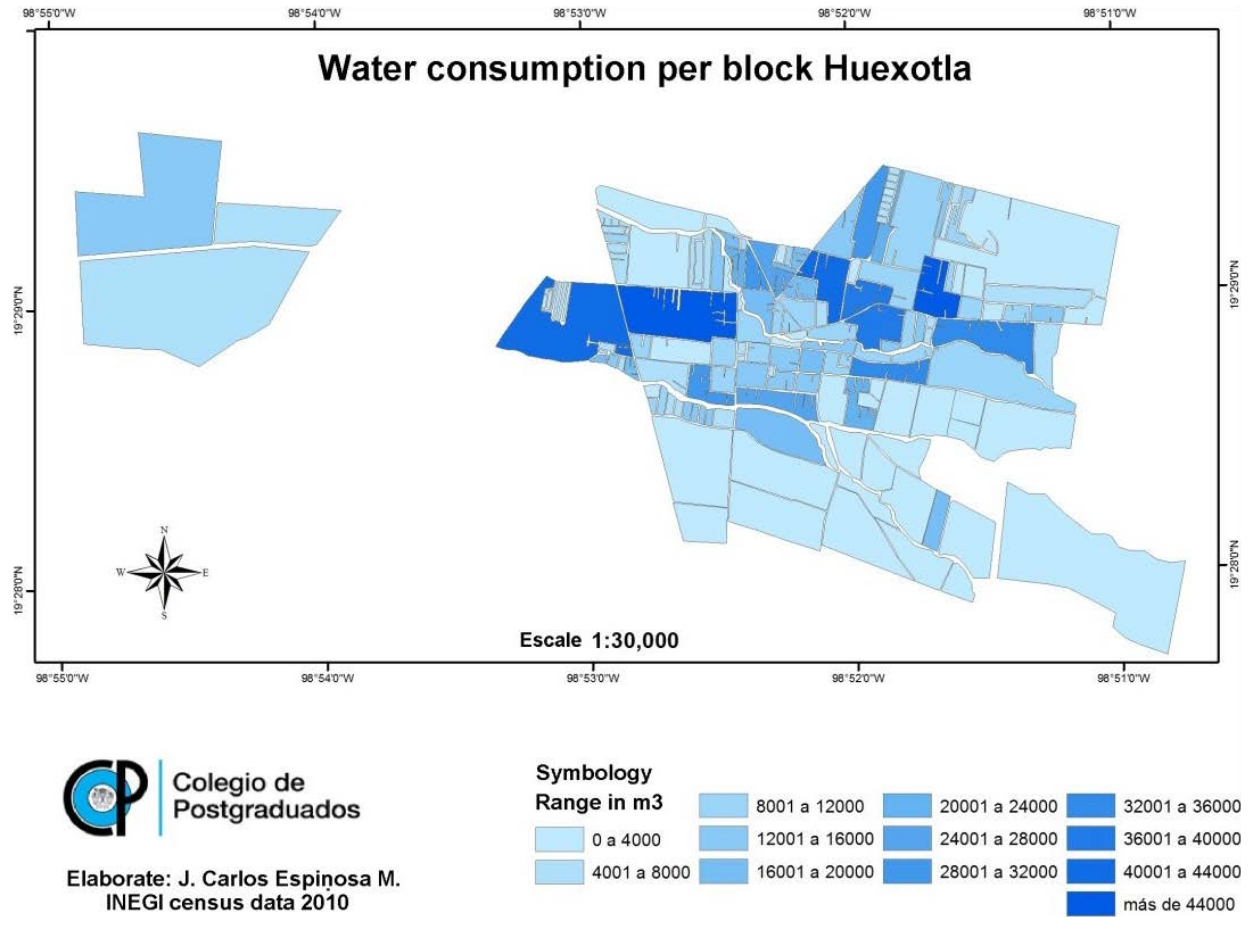

Figure 5. Map of water consumption per block.

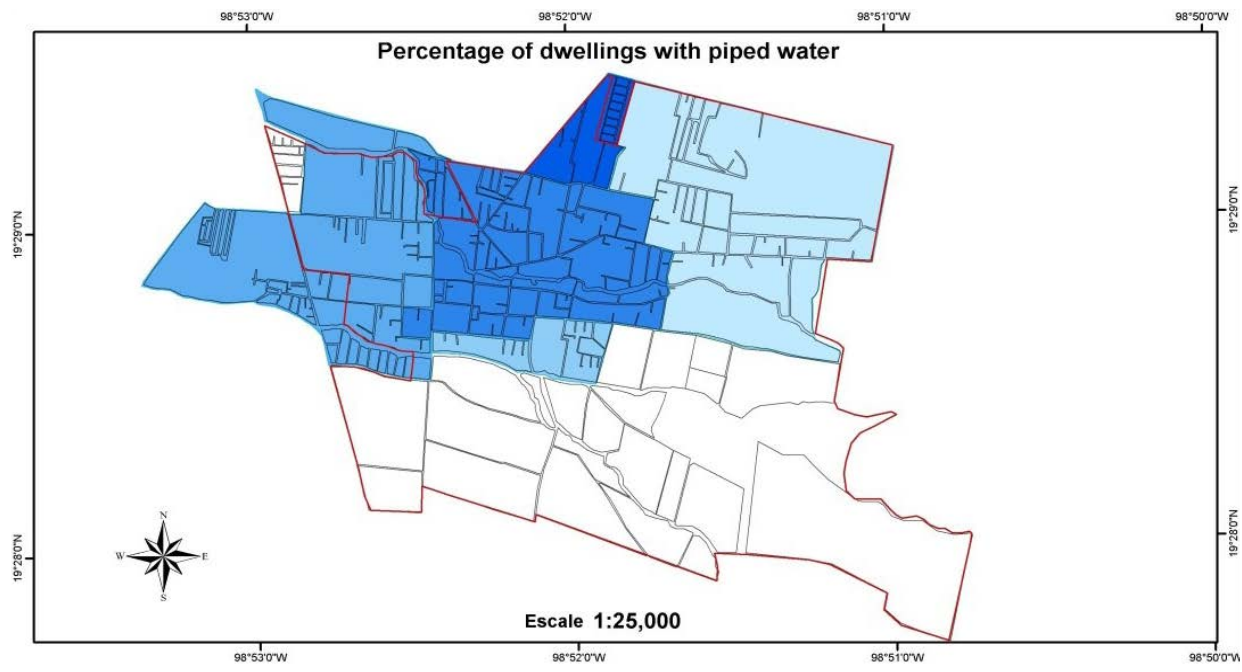

Figure 6. Percentage of dwellings with piped water per geostatistical basic unit (AGEB)

\begin{tabular}{|c|c|c|c|}
\hline Year & Population & Ton/day & Ton/Year \\
\hline 1980 & 3681 & 4.4 & 1612.3 \\
\hline 1990 & 7079 & 8.4 & 3100.6 \\
\hline 2000 & 9992 & 12.0 & 4376.5 \\
\hline 2010 & 12269 & 14.7 & 5373.8 \\
\hline Total & 33021 & 31.1 & 11362.6 \\
\hline
\end{tabular}


CONAGUA (2009). Y tú, ¿Derrochas el agua? Revista del Consumidor en línea. Posted 26 octubre. Consultado en: http://revistadelconsumidor.gob.mx/?p=5226.

Dixon, J.A. y Fallon, L.A. (1991) El concepto de sustentabilidad: sus orígenes, alcance y utilidad en la formulación de políticas», Desarrollo y medio ambiente Vidal, J. (Comp.), Santiago de Chile, CIEPLAN.

Espinosa Morales J.C., Escalona Maurice M.J., Fernández Ordoñez Y.M., (2017) Análisis territorial mediante un modelo cartográfico en San Luis Huexotla, Texcoco México. Revista Agroproductividad Vol. 10, Núm. 5. Pp:77-85

H. Ayuntamiento de Texcoco (2016). Plan de Desarrollo Municipal de Texcoco 2016 - 2018

INEGI, (2010). Censos Generales de Población y Vivienda 1980, 1990, 2000 y 2010.

INEGI (2010b). Áreas Geoestadísticas Básicas Rurales y Urbanas. INEGI, México.

INEGI (2015). Encuesta Intercensal. México.

Ki-moon Ban (2000). El agua es vida. Artículo de opinión. Naciones Unidas. Consultado en: http://www.cinu.org.mx/prensa/opeds/20080PEDaguaesvida.html

López, B. J.; Rodríguez G. M. L. 2008. Desarrollo de indicadores ambientales y de sustentabilidad en México. Instituto de Geografía, UNAM. P 21.

Martínez, M. (1991). La investigación cualitativa etnográfica en educación: Manual teórico práctico. Venezuela. Texto.

Molero M. E., Grindlay Moreno, A. L. Asensio Rodríguez, J. J. (2007): "Escenarios de aptitud y modelización cartográfica del crecimiento urbano mediante técnicas de evaluación multicriterio", GeoFocus (Artículos), no 7, p. 120- 147. ISSN: 1578-5157.

OCDE (1993). Indicators for the Integration of Environmental Concerns into Energy Policies. Environment Monographs 79. France.

Ortega Pérez E., Martin Ramos R., Ezquerra Canalejo A., Otero Pastor I., (2016). Sistemas de Información Geográfica. Teoría y Práctica. Drextra. España.

SEMARNAT (2016). Sistema Nacional de Indicadores Ambientales (SNIA). México.

SEMARNAT (2018). Informe de la situación de Medio Ambiente en México. "Compendio de estadísticas ambientales, Indicadores clave, desempeño ambiental y crecimiento verde.

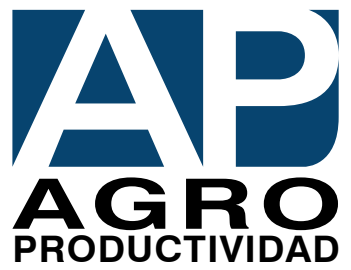

